\title{
USE OF IMMUNOHISTOCHEMISTRY IN THE DIFFERENTIAL DIAGNOSIS OF SMALL ROUND BLUE CELL TUMORS.
}

\footnotetext{
1. MBBS, FCPS

Assistant Professor \& Head

Pathology Department

Batterjee Medical College, Jeddah, Saudi Arabia.

2. MBBS, M.Phil

Associate Professor

Pak International Medical College, Peshawar, Pakistan.

3. MBBS, M.Phil

Professor \& Head Pathology

University Medical and Dental

College, Faisalabad, Pakistan.

4. MSc, M.Phil

Freelancer

Faisalabad, Pakistan.

5. MBBS, FCPS

Assistant Professor Pathology College of Medicine, University of Bisha, Saudi Arabia.

6. MBBS, PGMI

Medical Officer

Federal Government Poly Clinic

Institute, Islamabad, Pakistan.
}

Correspondence Address:

Dr. Muhammad Mudassar

Department of Pathology

Batterjee Medical College, Jeddah,

Saudi Arabia.

drmudassarmajeed@gmail.com

Article received on:

24/03/2020

Accepted for publication:

$15 / 05 / 2020$
Muhammad Mudassar ${ }^{1}$, Farhan Abbas Baloch ${ }^{2}$, Sadia Hameed ${ }^{3}$, Saima Zubair ${ }^{4}$, Shahzada Khalid Sohail ${ }^{5}$, Muhammad Kamran ${ }^{6}$

ABSTRACT... Objectives: Objective of the study is to differentiate and sub-categorize malignant small round blue cell tumors by using immuneO-histochemistry. Study Design: Descriptive Observational study. Setting: Meezan Private Lab, Faisalabad, Pakistan. Period: 5 years, from July 2014 to June 2019. Material \& Methods: 126 cases of Round blue cells tumors selected by non probability purposive sampling. 126 cases which fulfilled the inclusion and exclusion criteria were selected for the study. All these cases were subjected to immunohistochemistry. The IHC technique used was based on Peroxidase anti-peroxidase (PAP) method. Based on site and morphological clues, initially Leukocyte common antigen (LCA), Myogenin, Cytokeratin (CK), Desmin, chromogranin, Neuron specific enolase (NSE), S-100, Smooth muscle actine (SMA) and CD99 were used. Further immune stains panels were used afterwards, as and when needed like CD20, CD3, CD30, BCL2, CD117, Ki-67, Tdt, synaptophysin, SMA, CD56, Melan A, HMB45 and WT1. Results: Out of 126 cases of small round blue cell tumors, 35 (27.8 \%) cases were diagnosed as diffuse large B cell lymphoma, 6 as Lymphoblastic lymphoma, 4 as Burkitt's lymphoma, and 6 cases as NK/T cell lymphoma. Ewing's sarcoma/PNET (12/126, $9.5 \%)$ was the $2^{\text {nd }}$ highest in frequency, followed by Rhabdomyosarcoma, Synovial sarcoma, Malignant melanoma, and Germ cell tumor, which were all 9/126 each with $7.1 \%$. Conclusion: Immunohistochemistry is an important tool for appropriate and clear differential diagnosis of malignant small round blue cell tumors of childhood.

Key words: Differential Diagnosis of Round Blue Cell Tumor, Imunohistochemistry, Malignant Small Round Blue Cell Tumor, MSRBCT, Round Blue Cell Tumor.

\footnotetext{
Article Citation: Mudassar M, Baloch FA, Hameed S, Zubair S, Sohail SK, Kamran M. Use of Immunohistochemistry in the differential diagnosis of Small Round Blue cell tumors. Professional Med J 2020; 27(8):1728-1736.

DOI: 10.29309/TPMJ/2020.27.08.4670
}

\section{INTRODUCTION}

Small round blue cell tumors (SRBCT) is a diagnosis rendered on routine histopathology to the diverse groups of tumors. These tumors show remarkable resemblance with each other, in spite of the fact that; they originate from various different tissues namely epithelium, soft tissue, lymphocytes, bone, muscles, nerves cells and even melanocytes. ${ }^{1}$ Microscopically, these are highly undifferentiated tumors, containing a monotonous population of small round cells with increased nuclear and cytoplasmic ratio. ${ }^{2}$ Moreover, these primitive cells lack features of their histiogenetic origin on routine $\mathrm{H} \& \mathrm{E} .^{3}$ There is a long list of tumors which are included in this entity, noteworthy mentions are Non-Hodgkin lymphomas, Retinoblastoma, Hepatoblastoma, Neuroblastoma, Synovial Sarcoma, Ewing Sarcoma/ Primitive Neuroectodermal Tumor, Undifferentiated Neuroendocrine carcinoma, Desmoplastic Small Round Cell Tumor, Dysgerminoma, Osteosarcoma, Wilm's tumor, Mesenchymal Chondrosarcoma, Malignant Melanoma (Small Cell variant), Nasopharyngeal Carcinoma and Rhabdomyosarcoma. ${ }^{2,4-6}$ The list can be expanded if we consider site-specific round cell tumors. ${ }^{7-9}$ These tumors are commonly seen in the children but can also be found in adults. ${ }^{10}$

As we can see from the above discussion that the differential diagnosis of SRBCT includes a 
diverse group of tumors and the treatment and management of each differential is quite different. For example; targeted therapy of anti-CD20 is effective in CD20 positive lymphoma whereas chemotherapy is the mainstay of treatment in sarcomas and lymphoma, extragonadal germ cell tumors and neuroendocrine tumors. Melanomas are treated by surgery and interferon. Furthermore, management of Desmoplastic Small Round Cell Tumor is quite different from the rest of the lot.411-13 To solve the dilemma of accurate differential diagnosis, many diagnostic modalities are in practice. This includes IHC (immunohistochemistry) ${ }^{10}, \mathrm{FISH}$ (Fluorescence in situ hybridization) ${ }^{14}$, electron microscopy, cytogenetics, molecular techniques ${ }^{15}$ and reverse transcriptase polymerase chain reaction (RT-PCR). ${ }^{6,16}$ Molecular techniques are best for confirmation but their high cost and sophisticated instruments limit their use in resource-poor countries. ${ }^{17}$ However, a technique which is less costly, practised worldwide and can differentiate SRBCT to a greater extent is immunohistochemistry (IHC).

Pakistan is a third world country, in which sophisticated techniques for accurate differential diagnosis are available only in few setups, which are beyond the reach of the common man. Faisalabad is the third-largest city of Pakistan, but it lacks up-to-date diagnostic setups. Even the $\mathrm{IHC}$ is not available in any government or private setups to date. Most of the complicated and disputed cases are referred to referral labs in other parts of the country, which delays the proper management and increases the cost of treatment of these highly aggressive tumors. In view of this scenario, collaborations have been established to provide IHC as a routine modality for all problematic histopathological cases.

To evaluate the role of immuno-histochemistry in the differentiation and sub-categorization of malignant small round blue cell tumors.

\section{MATERIAL \& METHODS}

This descriptive observational study was conducted at Meezan private lab Faisalabad, Pakistan, from July 2014 to June 2019. Total of 126 cases of Round blue cells tumors were included in the study. The sampling technique was non-probability purposive. All cases of round blue cell tumor were included in the study that were diagnosed on routine hematoxylin and eosin staining and then subjected to immunohistochemistry for confirmation and sub-typing. However, the autolyzed tissues and cases in which the immunohistochemistry was not done, because of technical or logistics issues were excluded from the study.

The IHC technique used was based on Peroxidase anti-peroxidase (PAP) method. The protocol used is as following:

1. Cut tissue sections 2.0 - 4.0 microns thick and spread wrinkle-free on the slide.

2. Put the slides on Hot plate $60^{\circ}-65^{\circ}$ for 45 to 50 $\min$

3. For deparaffinisation, give 3-changes of Xylene 5 min each.

4. Rehydrate the tissue with graded isopropanol (100\%, 80\%, 70\%, 50\%) 5 min each.

5. Put distilled water for 3 to 5 min two changes

6. Then put in antigen retrieval solution (target retrieval solution) in Kortil Coplin Jar: Dilution 1:50. pH must be 9.0 for CD5, CD10, CD3, CD30, CD99 and 2.5pH for Myogenin, Ki-67, WT1. All remaining should have $\mathrm{pH} 6$.

7. Put in a water bath at $99.5^{\circ}$ for 45 mins - 1 hour

8. Take out from water bath and put at room temperature

9. Then wash in wash buffer solution for $10 \mathrm{~min}$, two changes. Dilution 1:20 (pH must be 7.6)

10. Pour peroxidase blocking reagent on slide covering the tissue area and put in Humidity chamber for $10 \mathrm{~min}$

11. Wash again in wash buffer for $10 \mathrm{~min}$, two changes

12. Pour 50 ul of primary antibody on tissue area and put in Humidity chamber for 45 min to 1 hour (as per literature)

13. Again wash in wash buffer for $10 \mathrm{~min}$, two changes

14. Pour 50 ul of the secondary antibody (HRP) on tissue area and put in Humidity chamber for 45 min to 1 hour.

15. Wash again in wash buffer for $10 \mathrm{~min}$, two 
changes.

16. Add Dabe chromogen 50 ul on tissue area for 3-5 min (Dabe chromogen 50 ul and substrate $1 \mathrm{ml})$

17. Wash in distilled water 3 to $5 \mathrm{~min}$

18. Counterstain with hematoxylin by 3-5 dips, a stain must be filtered periodically

19. Wash in Tap water for 3 to 5 min

20. Put the slides rack in Propanol for 3 cycles of $5 \mathrm{~min}, 3 \mathrm{~min}$ and $5 \mathrm{~min}$ respectively.

21. Air dry and give 3 cycles of Xylene 5 min, 3 min, and 5 min respectively.

22. Mounting with DPX (DisrteneDibutyl-Phthalate Xylene) and then observe the slide.

Based on-site and morphological clues, initially Leukocyte common antigen (LCA), Myogenin, Cytokeratin (CK), Desmin, chromogranin, Neuron-specific enolase (NSE), S-100, Smooth muscle actin (SMA) and CD99 were used. Further immune stains panels were used afterwards, as and when needed like CD20, CD3, CD30, BCL2, CD117, Ki-67, Tdt, synaptophysin, SMA, CD56, Melan A, HMB45, PAX5, Calretinin and WT1. The results were analyzed independently by 2 histopathologists. Staining intensity was graded as negative, or weak, moderate to strong positive. The extent of positive IHC reaction was scored as focal $(<10 \%)$, patchy $(10-50 \%)$ or diffuse $(>50 \%) .{ }^{18}$ and the final diagnosis was rendered.

All the collected information was entered and analyzed using SPSS version 24 . The qualitative variables like gender, site and diagnosis were presented by calculating frequency and percentage.

\section{RESULTS}

Out of total 126 cases of Malignant Small round blue cell tumors, 51 (40.6\%) cases were diagnosed as lymphoma, after combining diffuse large $B$ cell lymphoma(35), T lymphoblastic lymphoma(6), Burkitt's lymphoma(4), and NK/T cell lymphoma(6). Ewing's sarcoma/PNET $(12 / 126,9.5 \%)$ was the $2^{\text {nd }}$ highest in frequency, followed by rhabdomyosarcoma, Synovial sarcoma, malignant Melanoma, and Germ cell tumor, which were all 9/126 each with 7.1 $\%$. Individually Diffuse large B cell Iymphoma

(DLBCL) was the highest with the frequency of $35 / 126$ and percentage of $27.8 \%$ (See Table-I). $52 \%(66 / 126)$ of SRBCT were seen between the ages of 13-55 years. Second highest was seen below 5 years of age i.e. 36/126 (28\%). People older than 56, the no of cases of SRBCT were the least (24, 19\%). Rhabdomyosarcoma was highest in the 1-12 years belt (7/9), Melanoma was highest in 56-100 years age group (6/9) and DLBCL was significantly higher in 13-55 years range (21/35). (See Table-I). Site wise distribution of all cases was highlighted in Table-III.

Males were showing a higher number of many tumors including DLBCL and Ewing's Sarcoma, while Neuro-endocrine and Adrenocortical neoplasms were increased in Females. (Figure-1). There are two cases, one from the ankle joint and other from the pelvic area, which remained unclassified even after use of all available panels of antibodies in our set up.

\begin{tabular}{|l|c|c|}
\hline \multicolumn{1}{|c|}{ Diagnosis } & Frequency & Percent \\
\hline $\begin{array}{l}\text { Diffuse Large B Cell } \\
\text { Lymphoma }\end{array}$ & 35 & 27.8 \\
\hline T Lymphoblastic lymphoma & 6 & 4.8 \\
\hline Burkitt's lymphoma & 4 & 3.2 \\
\hline NK/T cell lymphoma & 6 & 4.8 \\
\hline Nasopharyngeal carcinoma & 4 & 3.2 \\
\hline Ewing's sarcoma/PNET & 12 & 9.5 \\
\hline Rhabdomyosarcoma & 9 & 7.1 \\
\hline Synovial sarcoma & 9 & 7.1 \\
\hline Malignant Melanoma & 9 & 7.1 \\
\hline Neuroblastoma & 5 & 4.0 \\
\hline Germ cell tumor & 9 & 7.1 \\
\hline Rhabdoid tumor & 1 & 0.8 \\
\hline $\begin{array}{l}\text { Desmoplastic Small Round } \\
\text { cell tumor }\end{array}$ & 1 & 0.8 \\
\hline Retinoblastoma & 5 & 0.8 \\
\hline $\begin{array}{l}\text { Neuroendocrine tumor, low } \\
\text { grade }\end{array}$ & 5 & 4.0 \\
\hline Small cell carcinoma & 3 & 2.4 \\
\hline Adrenocortical neoplasm & 126 & 100.0 \\
\hline $\begin{array}{l}\text { Round blue cell tumor, } \\
\text { Unclassified }\end{array}$ & 5 & 4.6 \\
\hline Total & \multicolumn{1}{|c|}{$\begin{array}{l}\text { Table-I. Frequency of differential diagnosis of } \\
\text { malignant small round blue cell tumors. }\end{array}$} \\
\hline
\end{tabular}




\begin{tabular}{|c|c|c|c|c|}
\hline \multirow{2}{*}{$\begin{array}{l}\text { Differential Diagnosis of Round Blue Cell } \\
\text { Tumors }\end{array}$} & \multicolumn{3}{|c|}{ Age Groups (years) } & \multirow{2}{*}{ Total } \\
\hline & 1 to 12 & 13 to 55 & 56 to 100 & \\
\hline Diffuse Large B Cell Lymphoma & 5 & 21 & 9 & 35 \\
\hline T Lymphoblatic lymphoma & 2 & 4 & 0 & 6 \\
\hline Burkitt's lymphoma & 3 & 1 & 0 & 4 \\
\hline Nk/T cell lymphoma & 1 & 4 & 1 & 6 \\
\hline Nasopharyngeal carcinoma & 0 & 4 & 0 & 4 \\
\hline Ewing's sarcoma/PNET & 5 & 6 & 1 & 12 \\
\hline Rhabdomyosarcoma & 7 & 1 & 1 & 9 \\
\hline Synovial sarcoma & 1 & 7 & 1 & 9 \\
\hline Malignant Melanoma & 1 & 2 & 6 & 9 \\
\hline Neuroblastoma & 3 & 1 & 1 & 5 \\
\hline Germ cell tumor & 4 & 5 & 0 & 9 \\
\hline Rhabdoid tumor & 1 & 0 & 0 & 1 \\
\hline Desmoplastic Small Round cell tumor & 1 & 0 & 0 & 1 \\
\hline Retinoblastoma & 0 & 1 & 0 & 1 \\
\hline Neuroendocrine tumor, low grade & 0 & 4 & 1 & 5 \\
\hline Small cell carcinoma & 0 & 2 & 3 & 5 \\
\hline Adrenocortical neoplasm & 0 & 3 & 0 & 3 \\
\hline Round blue cell tumor, Unclassified & 2 & 0 & 0 & 2 \\
\hline Total & 36 & 66 & 24 & 126 \\
\hline
\end{tabular}

Table-II. Relationship of round blue cell tumor with different age groups

Diagnosis

Diffuse Large B Cell

Lymphoma

T Lymphoblastic lymphoma

Burkitt's lymphoma

$\mathrm{Nk} / \mathrm{T}$ cell lymphoma

Nasopharyngeal carcinoma

Ewing's sarcoma/PNET

Rhabdomyosarcoma

Synovial sarcoma

Malignant Melanoma

Neuroblastoma

Germ cell tumor

Rhabdoid tumor

Desmoplastic Small Round cell tumor

Retinoblastoma

Neuroendocrine tumor, low grade

Small cell carcinoma

Adrenocortical neoplasm

Round blue cell tumor, Unclassified
Site of Biopsy

Total

cases

Cervical lymph node (3), Inguinal lymph node(1), Liver mass(1), Nasopharynx (4), Stomach (1), Intestine (5), Bone (1), Testis (4), Chest mass (2), Abdominal mass(2), Pelvic mass(1), Retroperitoneum (1), skin (2), Tonsil (3), Joint (1), spleen (1), gluteal mass (1), Spine (1)

Cervical lymph node (3), Nasopharynx (2), Bone (1)

6

Liver mass(1), Nasopharynx (1), Intestine (2)

4

Cervical lymph node (1), Inguinal Nasopharynx (2), Abdominal mass(1), skin (1), Joint (1)

Cervical lymph node (3), Nasopharynx (1)

Cervical lymph node (3), Bone (2), Chest mass (5), Pelvic mass(1), Joint (1) 12

Cervical lymph node (3), Inguinal lymph node(1), Liver mass(1), Testis (1), Pelvic mass(1), Urinary bladder (1), Eye (1)

Cervical lymph node (1), Bone (1), Chest mass (2), Pelvic mass(1), Thigh mass(3), Joint (1)

Cervical lymph node (1), Inguinal lymph node(2), Liver mass(1), Abdominal mass(1), skin (4)

Cervical lymph node (1), Nasopharynx (1), Retroperitoneum (3)

Cervical lymph node (1), Testis (4), Abdominal mass(2), Pelvic mass(1), Ovary (1)

Kidney(1)

Abdominal mass(1)

6

4

12

9

9

Eye (1)

1

Cervical lymph node (1), Intestine (2), Bone (1), Abdominal mass(1), Pelvic mass(1)

Cervical lymph node (1), Brain (1), Intestine (1), Bone (2),

Abdominal mass(2), Retroperitoneum (1)

Pelvic mass(1), Joint (1)

Table-III. Distribution of cases with their site of origin. 


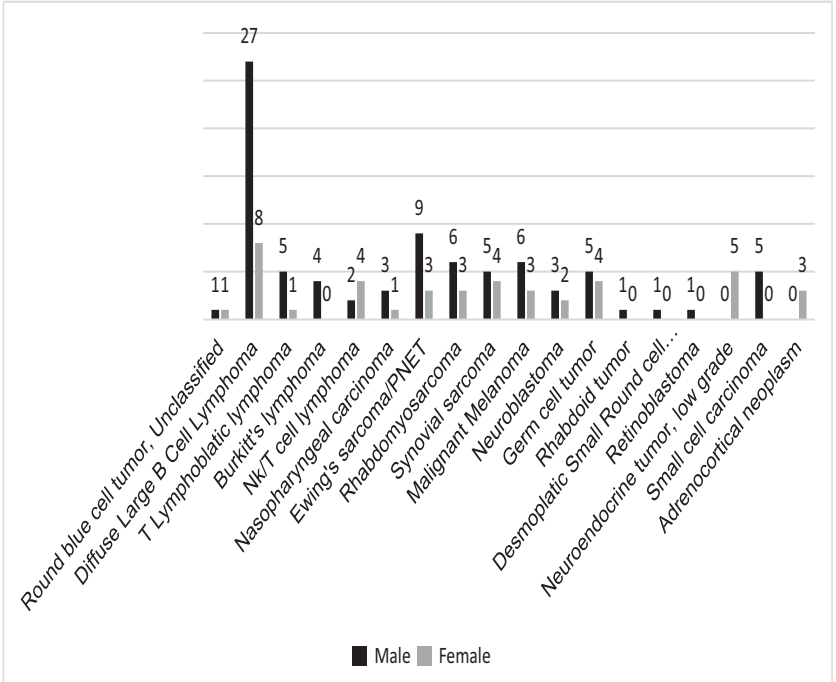

Figure-1. Relationship of round blue cell tumor frequency with gender

\section{DISCUSSION}

The usefulness of immunohistochemistry especially for small round blue cell tumor is established by a number of studies. ${ }^{19-23}$ Thomas et al reported that immunohistochemistry changed the diagnosis of $24 \%$ of the cases. $^{3}$ In our study, we used time tested panel of antibodies which have been narrated in the literature $2,4,10,17,24-26$, including Leukocyte common antigen (LCA), Myogenin, Cytokeratin (CK), Desmin, chromogranin, Neuron-specific enolase (NSE), S-100, Smooth muscle actin (SMA) and CD99 were used. Further immune stains panels were used afterwards, as and when needed like CD20, CD3, CD30, BCL2, CD117, Ki-67, Tdt, synaptophysin, SMA, CD56, Melan A, HMB45, PAX5, Calretinin and WT1. However, many novel antibodies have also been used in other studies; like PAX7 ${ }^{21}, \mathrm{NKX} 2.2^{18}, \mathrm{PHOX}^{2} \mathrm{~B}^{20}, \mathrm{BCOR}^{27}, \mathrm{ETV}^{28}$ and many more. Some of them claimed to be better and more specific than previously used. However financial constraints limited us to use these newer antibodies.

Diffuse large B cell lymphomas were the most common tumors among SRBCT in our study $35 / 126$ (27.8\%), Other NHL in differential were T lymphoblastic lymphoma(4), Burkitt's lymphoma(3), and NK/T cell lymphoma(1). (See Table 1). This finding was consistent with Thomas et $\mathrm{al}^{3}$, Patel et $\mathrm{al}^{10}$ and Bashyal et $\mathrm{al}^{29}$, in which

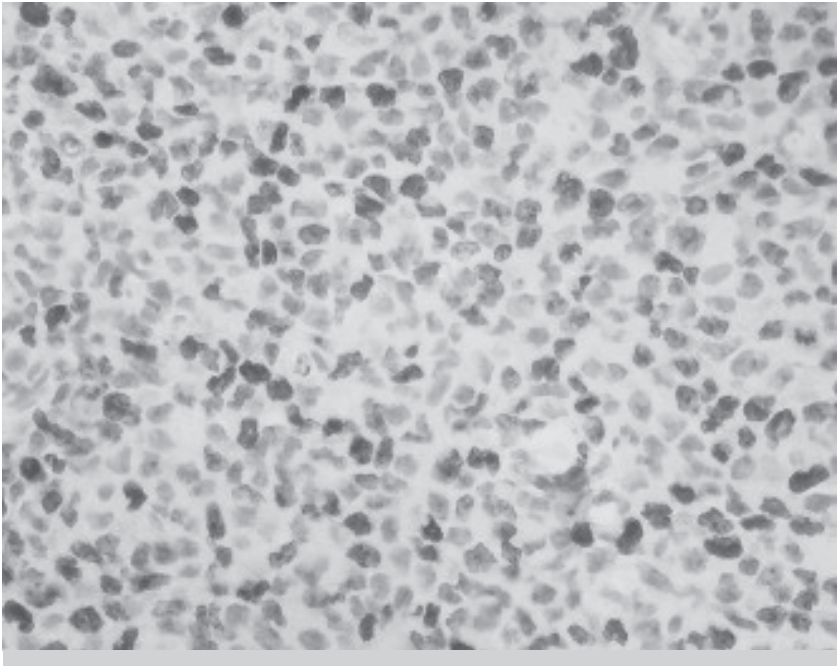

Figure-2. Ki-67 Immunohistochemical stain on a case of Diffuse Large B cell lymphoma with $70 \%$ positivity (Brown color) (Magnification $x$ 400)

lymphomas were the most common among small round blue cell,. However, the exact percentages were variable in all studies, probably due to geographical, racial and sampling differences. Among SRBC tumors of the head-neck region, not only lymphomas but carcinomas were also higher (36.36\% each). ${ }^{30} \mathrm{~A}$ possible explanation is that this area particularly harbours more carcinomas than lymphomas..$^{6,7}$ Based on this, it can be said that IHC used to differentiate SRBCT must always include lymphoma panel. i.e LCA(CD45), CD20, CD3, CD30, Cyclin D1, Tdt, CD5, Ki-67 etc. The specialized antibodies like PAX 5, BCL2, CD10, ALK etc can be added to this panel ${ }^{31-34}$, as the need arises. The same approach was adopted in our study. DLBCL was biopsied from multiple sites notably cervical lymph nodes (3), Nasopharynx (4), Intestine (4), Testis (4), Tonsil (3) and Spine (1). (See Table 3). This feature was consistent with Patel et al. ${ }^{4}$ Regarding age distribution, we noticed maximum cases $(21 / 35,60 \%)$ of DLBCL in the 13-55 year age group, 9 cases in $\square 56$ years age group, and only 5 cases below 12 years age. The males were significantly involved more than females, i.e. $27 / 35,77 \%$. The male predominance of DLBCL was also reported in other studies. ${ }^{35}$

Ewing's Sarcoma/PNET was $2^{\text {nd }}$ most common tumor in our study comprising of 12/126 tumors $(9.5 \%)$. Our finding was matching with Shi Wei etal, who stated that it is $2^{\text {nd }}$ most common bone 
malignancy in children and young adults with $6-8 \%$ incidence and $20 \%$ could be extra skeletal. ${ }^{14}$ The common site of origin in our study was chest mass (5), followed by cervical area (3), Bone (2), Pelvic mass (1) and Joint (1) (See Table 3). Extraskeletal sites of thigh and shoulder were also noticed in Patel et al. ${ }^{4}$ Ewing's/PNET are grouped together because they share the common cytogenetic abnormality and morphology. It has been said that Ewing's sarcoma of bone is undifferentiated, while PNET displays some degrees of neuroectodermal differentiation. ${ }^{5}$ $6 / 12,50 \%$ cases of this tumor were seen in the 13 to 55 age group and 5/12, 41.6\% were below 12 . Only 1 case was older than 55 years. This feature was highlighted by Narayanan et $\mathrm{al}^{8}$, Shi Wei et $\mathrm{al}^{14}$ and Magro et $\mathrm{al}^{19}$ mentioning that this tumor involves mainly children and young adults. This tumor was more common in males in our study $9 / 12,75 \%$, which was also mentioned by other studies. ${ }^{6,14}$

Rhabdomyosarcoma was among the $3^{\text {rd }}$ highest tumor in this category 9/126(7.1\%). Many studies reported that Rhabdomyosarcoma was the most common soft tissue malignancy of childhood with an estimated $40 \%$ incidence. ${ }^{2,36}$ It was contrary to our study. Since our study included both children and adults, so it is explainable that Rhabdomyosarcoma was not the most common tumor. Rhabdomyosarcoma was biopsied from the cervical region (3), inguinal region (1), liver (1), testis (1), Pelvic mass (1), urinary bladder (1) and eyelid(1). The same variability in the site of origin has been noticed in other articles also. ${ }^{2,25,36}$ The antibody myogenin was positive in all of the cases and desmin was positive in 3 cases.

Synovial sarcoma were 9/126 (7.1\%) in number. They were characteristically higher in the 13-55 age group $(7 / 9,77 \%)$ and slightly higher in male $(5 ; 4)$ and biopsy is taken from thigh mass (3), pelvic mass (1), Bone (1), Joints (1), chest mass (1) and cervical lymph node (1). The sites near the vicinity of joints like thigh and knee are stated by Rajwanshi et al. ${ }^{5} \mathrm{CK}$ with dot-like positivity was noticed in 8/9 cases. CD 99 was positive in 4/9 cases.
Malignant melanomas were also 9/126 (7.1\%) in number, making them $3^{\text {rd }}$ most common in our study. The most common site of the biopsy was skin (4), followed by inguinal lymph node (2), cervical lymph node (1), liver mass (1) and abdominal mass (1). 6/9 (66.6\%) cases were seen in $\square 56$ years of age. This was reported by other studies also.6,29 Germ cell tumors in our research were also $9 / 126(7.1 \%)$, with sites of testis (4), Abdominal mass (2), pelvic mass (1), cervical lymph node (1) and ovary (1). (Table-III).

Neuroblastoma, Neuro-endocrine tumor, low grade, and Small cell carcinoma, all were 5 out of 126 in our study with a percentage of $4 \%$. Sharma et al described Neuoblastoma as $3^{\text {rd }}$ most malignant extracranial solid tumor of childhood, arising from primitive neural crest cells. ${ }^{2}$ In our study 3 out of 5 of Neuroblastoma originated from retroperitoneum, and 3/5 cases were seen in less than 12 years of age (see table 2), which is consistent with Rajwanshi et al. ${ }^{5}$ Most of the cases of Neuroblastoma were positive CD 56 and chromogranin. In our study we found Small cell carcinoma to be $4 \%$, which is near to Patel A et al who reported as $5.26 \%$ and Mandakinin et al as $6.25 \%$. Low-grade neuroendocrine tumor and small cell carcinoma were all above 13 years of age (see table 2). was the only case $(0.8 \%)$ of desmoplastic small round cell tumor in our study, originated from the abdominal mass. Bulbul et al. also stated that it has predilection for abdominal and pelvic cavity. ${ }^{13}$ In the current study slight male preponderance was noticed in neuroblastoma and desmoplastic small round cell tumor, which was also described by Rajwanshi et al. ${ }^{5}$ Immunohistochemistry not only helps to differentiate small round cell tumors, but also it has been used locally for adequate and accurate characterization of all malignant tumors. ${ }^{37}$

In our study, we found two cases (1.6\%), one from the ankle joint and other from pelvic mass, which remained unclassified even after use of all available panels of antibodies in our set up. This was consistent with Patel et $\mathrm{al}^{10}$, who reported $3.75 \%$ of cases that could not be classified. The reason in our case was unequivocal results of $\mathrm{IHC}$ markers. In such cases, sophisticated techniques 
like electron microscopy, cytogenetics and molecular studies become essential for final diagnosis.

\section{LIMITATION OF STUDY}

Correlation with cytogenetics and other molecular techniques were not done because of cost and availability issues. Scarcity of resources also handicapped us to use novel immunohistochemical antibodies, which can be more promising and specific. We recommend future studies to be conducted, tackling the above-mentioned deficiencies.

\section{CONCLUSION}

Malignant small round blue cell tumors are a diverse group of tumors. Immunohistochemistry is an important tool for appropriate and clear differential diagnosis of these tumors. It will facilitate the timely and accurate management of these cases.

\section{ACKNOWLEDGEMENTS}

The authors are thankful to the laboratory staff of the Histopathology section of Fatima Memorial Hospital for their contribution in immunohistochemistry. We also deeply appreciate the doctors and staff of Meezan Lab, Faisalabad for their ultimate and never-ending support and cooperation.

\section{CONFLICTS OF INTEREST}

None

Copyright@ 15 May, 2020.

\section{REFERENCES}

1. Bridge JA, Bowen JM, Smith RB. The small round blue cell tumors of the sinonasal area. Head and neck pathology. 2010;4(1):84-93.

2. Sharma S, Kamala R, Nair D, Ragavendra TR, Mhatre S, Sabharwal R, et al. Round cell tumors: Classification and immunohistochemistry. Indian journal of medical and paediatric oncology: official journal of Indian Society of Medical \& Paediatric Oncology. 2017; 38(3):349-53.

3. Thomas JO, Olu-Eddo AA. Immunocytochemistry in the diagnosis of small blue cell tumours of childhood. West African journal of medicine. 2006; 25(3):199-204.
4. Patel A, Patel M, Bhagat V, Naik K. Role of immunohistochemistry in the differential diagnosis of malignant small round cell tumor: A study of $\mathbf{3 8}$ cases. International Journal of Research in Medical Sciences. 2015; 3833-9.

5. Rajwanshi A, Srinivas R, Upasana G. Malignant small round cell tumors. Journal of cytology. 2009; 26(1):110.

6. Thompson LD. Small round blue cell tumors of the sinonasal tract: A differential diagnosis approach. Modern pathology: An official journal of the United States and Canadian Academy of Pathology, Inc. 2017; 30(s1):S1-S26.

7. Rooper LM, Bishop JA. Sinonasal small round blue cell tumors: An immunohistochemical approach. Surgical pathology clinics. 2017; 10(1):103-23.

8. Narayanan G, Rajan V, Preethi TR. Primitive neuroectodermal tumors of the kidney. Proceedings. 2017; 30(2):205-8.

9. Tsukamoto Y, Futani H, Yoshiya S, Watanabe T, Kihara T, Matsuo S, et al. Primary undifferentiated small round cell sarcoma of the deep abdominal wall with a novel variant of $t(10 ; 19)$ CIC-DUX4 gene fusion. Pathology, research and practice. 2017; 213(10):1315-21.

10. Patel MM, Dhandha ZB, Italiya SL, Shah MB, Kaptan $\mathrm{KR}$, Mansuri BM, et al. Role of immunohistochemistry in differential diagnosis of round cell tumor. Indian $\mathrm{J}$ Res. 2013; 3(5):217-20.

11. Frezza AM, Benson C, Judson IR, Litiere S, Marreaud S, Sleijfer S, et al. Pazopanib in advanced desmoplastic small round cell tumours: A multi-institutional experience. Clinical sarcoma research. 2014; 4:7.

12. Menegaz BA, Cuglievan B, Benson J, Camacho P, Lamhamedi-Cherradi SE, Leung $\mathrm{CH}$, et al. Clinical activity of pazopanib in patients with advanced desmoplastic small round cell tumor. The oncologist. 2018; 23(3):360-6.

13. Bulbul A, Fahy BN, Xiu J, Rashad S, Mustafa A, Husain $\mathrm{H}$, et al. Desmoplastic Small Round Blue Cell Tumor: A Review of Treatment and Potential Therapeutic Genomic Alterations. Sarcoma. 2017;2017:1278268.

14. Wei S, Siegal GP. Round cell tumors of bone: An update on recent molecular genetic advances. Advances in anatomic pathology. 2014; 21(5):359-72. 
15. Koelsche C, Hartmann W, Schrimpf D, Stichel D, Jabar S, Ranft $A$, et al. Array-based DNA-methylation profiling in sarcomas with small blue round cell histology provides valuable diagnostic information. Modern pathology: An official journal of the United States and Canadian Academy of Pathology, Inc. 2018; 31(8):124656.

16. Owosho AA, Estilo CL, Huryn JM, Zhang L, Fletcher CDM, Antonescu CR. Head and neck round cell sarcomas: A comparative clinicopathologic analysis of 2 molecular subsets: Ewing and CIC-Rearranged Sarcomas. Head and neck pathology. 2017; 11(4):4509.

17. Li Q, Cui W, Abulajiang G, Ma Y, Liu X, Zhang W, et al. Application of immunohistochemistry in the diagnosis of small round blue-cell tumors of soft tissue. Clinical laboratory. 2014; 60(8):1383-92.

18. Machado I, Yoshida A, Morales MGN, Abrahao-Machado LF, Navarro S, Cruz J, et al. Review with novel markers facilitates precise categorization of 41 cases of diagnostically challenging, "undifferentiated small round cell tumors". A clinicopathologic, immunophenotypic and molecular analysis. Annals of diagnostic pathology. 2018; 34:1-12.

19. Magro G, Brancato F, Musumeci G, Alaggio R, Parenti R, Salvatorelli L. Cyclin D1 is a useful marker for soft tissue Ewing's sarcoma/peripheral Primitive Neuroectodermal Tumor in children and adolescents: A comparative immunohistochemical study with rhabdomyosarcoma. Acta histochemica. 2015; 117(45):460-7.

20. Bielle F, Freneaux P, Jeanne-Pasquier C, MaranGonzalez A, Rousseau A, Lamant L, et al. PHOX2B immunolabeling: a novel tool for the diagnosis of undifferentiated neuroblastomas among childhood small round blue-cell tumors. The American journal of surgical pathology. 2012; 36(8):1141-9.

21. Charville GW, Varma S, Forgo E, Dumont SN, Zambrano E, Trent JC, et al. PAX7 Expression in Rhabdomyosarcoma, Related Soft Tissue Tumors, and Small Round Blue Cell Neoplasms. The American journal of surgical pathology. 2016;40(10):1305-15.

22. Marino-Enriquez A, Fletcher CD. Round cell sarcomas - biologically important refinements in subclassification. The international journal of biochemistry \& cell biology. 2014; 53:493-504.

23. Halliday BE, Slagel DD, Elsheikh TE, Silverman JF. Diagnostic utility of MIC-2 immunocytochemical staining in the differential diagnosis of small blue cell tumors. Diagnostic cytopathology. 1998; 19(6):410-6.
24. Folpe AL, Hill CE, Parham DM, O'Shea PA, Weiss SW. Immunohistochemical detection of FLI-1 protein expression: A study of 132 round cell tumors with emphasis on CD99-positive mimics of Ewing's sarcoma/primitive neuroectodermal tumor. The American journal of surgical pathology. 2000;24(12):1657-62.

25. Morotti RA, Nicol KK, Parham DM, Teot LA, Moore $J$, Hayes $J$, et al. An immunohistochemical algorithm to facilitate diagnosis and subtyping of rhabdomyosarcoma: The Children's Oncology Group experience. The American journal of surgical pathology. 2006; 30(8):962-8.

26. Yamada Y, Kuda M, Kohashi K, Yamamoto H, Takemoto $\mathrm{J}$, Ishii $\mathrm{T}$, et al. Histological and immunohistochemical characteristics of undifferentiated small round cell sarcomas associated with CIC-DUX4 and BCORCCNB3 fusion genes. Virchows Archiv : an international journal of pathology. 2017; 470(4):373-80.

27. Kao YC, Sung YS, Zhang L, Jungbluth AA, Huang SC, Argani $P$, et al. BCOR overexpression is a highly sensitive marker in round cell sarcomas with BCOR genetic abnormalities. The American journal of surgical pathology. 2016; 40(12):1670-8.

28. Le Guellec S, Velasco V, Perot G, Watson S, Tirode F, Coindre JM. ETV4 is a useful marker for the diagnosis of CIC-rearranged undifferentiated round-cell sarcomas: a study of 127 cases including mimicking lesions. Modern pathology: An official journal of the United States and Canadian Academy of Pathology, Inc. 2016; 29(12):1523-31.

29. Bashyal R, Pathak TB, Shrestha S, Pun CB, Banstola S, Neupane $S$ et al. Role of immunohistochemistry in the diagnosis of malignant small round cell tumors. JPN. 2011; 1:87-91.

30. Bianchini WA, Altemani AM, Paschoal JR. Undifferentiated head and neck tumors: the contribution of immunohistochemical technique to differential diagnosis. Sao Paulo medical journal = Revista paulista de medicina. 2003;121(6):244-7.

31. Higgins RA, Blankenship JE, Kinney MC. Application of immunohistochemistry in the diagnosis of non-Hodgkin and Hodgkin lymphoma. Archives of pathology \& laboratory medicine. 2008;132(3):441-61.

32. Disanto MG, Ambrosio MR, Rocca BJ, Ibrahim HA, Leoncini L, Naresh KN. Optimal Minimal Panels of Immunohistochemistry for Diagnosis of B-Cell Lymphoma for Application in Countries With Limited Resources and for Triaging Cases Before Referral to Specialist Centers. American journal of clinical pathology. 2016; 145(5):687-95. 
33. Gustafson S, Medeiros LJ, Kalhor N, Bueso-Ramos CE. Anaplastic large cell lymphoma: another entity in the differential diagnosis of small round blue cell tumors. Annals of diagnostic pathology. 2009; 13(6):413-27.

34. Wang HY, Zu Y. Diagnostic Algorithm of Common Mature B-Cell Lymphomas by Immunohistochemistry. Archives of pathology \& laboratory medicine. 2017; 141(9):1236-46.

35. Ognjanovic S, Linabery AM, Charbonneau B, Ross JA. Trends in childhood rhabdomyosarcoma incidence and survival in the United States, 1975-2005. Cancer. 2009; 115(18):4218-26.
36. Rashid NA, Abdallah BA, Ani MA, Yassin AA. Demographics and outcome of diffuse large B-cell Iymphoma patients in Hiwa Hospital - Iraq-KurdistanSulaimani. Iraqi Journal of Hematology. 2018; 7(2):55.

37. Ahmed Z, Azad NS, Bhurgari Y, Ahmed R, Kayani N, Pervez S, et al. Significance of immunohistochemistry in accurate characterization of malignant tumors. Journal of Ayub Medical College. 2006; 18(2):38-43.

\begin{tabular}{|c|c|c|c|}
\hline \multicolumn{4}{|c|}{ AUTHORSHIP AND CONTRIBUTION DECLARATION } \\
\hline Sr. \# & Author(s) Full Name & Contribution to the paper & Author(s) Signature \\
\hline 1 & Muhammad Mudassar & $\begin{array}{l}\text { Manuscript writing, Data } \\
\text { analysis and reference writing. }\end{array}$ & \\
\hline 2 & Farhan Abbas Baloch & $\begin{array}{l}\text { Data analysis, Data entry, } \\
\text { Manuscript writing. }\end{array}$ & \\
\hline 3 & Sadia Hameed & $\begin{array}{l}\text { Data collection, } \\
\text { Histopathological review. }\end{array}$ & \\
\hline 4 & Saima Zubair & Data collection, Data analysis. & \\
\hline 5 & Shahzada Khalid Sohail & $\begin{array}{l}\text { Review, Proof reading, } \\
\text { Histopathological review. }\end{array}$ & \\
\hline 6 & & $\begin{array}{l}\text { Result, Compilation, } \\
\text { Discussion. }\end{array}$ & \\
\hline
\end{tabular}

